\title{
Études écossaises
}

$20 \mid 2018$

The Construction and Reconstruction of Scotland

\section{Foreword}

Avant-propos

Cyril Besson

\section{(2) OpenEdition}

\section{Journals}

Édition électronique

URL : http://journals.openedition.org/etudesecossaises/1395

DOI : 10.4000/etudesecossaises. 1395

ISSN : 1969-6337

\section{Éditeur}

UGA Éditions/Université Grenoble Alpes

\section{Édition imprimée}

ISBN : 978-2-37747-047-1

ISSN : $1240-1439$

Référence électronique

Cyril Besson, «Foreword », Études écossaises [En ligne], 20 | 2018, mis en ligne le 01 avril 2018, consulté le 24 septembre 2020. URL : http://journals.openedition.org/etudesecossaises/1395 ; DOI : https://doi.org/10.4000/etudesecossaises.1395

Ce document a été généré automatiquement le 24 septembre 2020.

(c) Études écossaises 


\title{
Foreword
}

\author{
Avant-propos
}

Cyril Besson

\section{NOTE DE L'AUTEUR}

Due to the fact that too little material has been retained from the proposals sent to the journal, the theme of "Scottish Kitsch", previously announced as the main topic for this issue, is postponed until next year. A revised call for papers on the same topic will be issued in the weeks after the online publication of this issue.

I would like to sincerely express thanks to all the contributors, whose varied and thoughtprovoking papers testify to the vitality of Scottish studies.

1 If "construction" means, etymologically, "to heap together", it is striking that the more modern meaning of the word implies a process that does not bear the same overtones of near inadvertence. Instead, it entails an intentionality of some sort, a quasiMiltonian drive to inform an original chaos, a first step inscribing the prospective architect (or a more modest bricoleur) in a chain of constructions, reconstructions and, potentially, destructions, headed towards wherever the arrow of time leads-and not necessarily "with wand'ring steps and slow". "Construction", in any case, seems to be, or arise, of necessity, in more than one sense, and the word's intension implicitly posits that the human state of affairs rests on order, or the imposition thereof. of course, it is easy to postulate, in retrospect, the full mastery of intentionality as initially present in the constructive drive, thus leading one to rationalize through an a posteriori reconstruction, making the task of the observer, surveyor or, indeed, academic, that much more difficult if objectivity is to be attained.

2 This loaded concept, with its variously affixed derivatives, was the main theme for the 2017 SAES conference, and is the core topic of this year's issue of Scottish Studies / Études écossaises. 
3 The first series of papers deals with the construction of an identity for Scotland, specifically in the visual arts, at a time when visibility became the essence of national existence, and what remains of this heritage. Marion Amblard explains how their stay in Italy influenced many Scottish painters and led to the formation of a Scottish school of painting. Clarisse Godard Desmarets writes about the establishment of The Old Royal High School, a building in the Greek style erected between 1825 and 1829 by architect Thomas Hamilton (1784-1858) in Edinburgh, and how its preservation is now potentially at risk, due to the many redevelopment schemes in the city. Lauren Brancaz-McCartan analyses to what extent the two weeks that George IV spent in Edinburgh in 1822 can be viewed as a "mythomoteur", namely "a constitutive political myth" which triggered the construction of Scotland's dual Scottish/British identity after the defeat of Jacobitism and the collapse of the Radical War, through four of the works which English painter Joseph Mallord William Turner produced on the occasion of the royal visit.

4 The second group of texts deals with reconstruction, the second stage of the process, and in a sense the living tradition of an older past. Céline Savatier-Lahondès investigates the ways in which the pre-Roman and pre-Christian culture of the British and Irish Isles permeates the work of William Shakespeare, presenting some aspects of the (re)construction of the so called "Celtic" culture in Shakespearean drama, and what retrieving these references entails for both the older and the newer cultures. Blaise Douglas focuses on Ceòl mór, a type of music born in the 16th century and, for those who play it today, a means of preserving a historical inheritance. This cultural form of expression is so intimately linked with Scottish history that the almost religious deference it is shown by some is communicative of the fundamental need of protecting the nation's identity. Christelle Ferrere studies how Scotland has found with poetry a fruitful source to draw her identity from and how, from the time of the reestablishment of the Scottish Parliament, a multiplicity of Makars, a synonym for "poets laureate for Scotland", has come out on the local as well as on the national levels, these contemporary Makars taking part in the construction and reconstruction of the nation's identity.

5 The third part is concerned with expansion, the ways in which culture can also pave the way for "the future" at given points in time, and not just that of Scotland, and deals with issues more directly aligned with widely discussed contemporary debates. Arnaud Fiasson examines how agents of the Scottish renaissance took it on themselves to revive the dormant national feeling so as to trigger a national movement that might match the national and international expectations of the Scottish nation; as a consequence, the polyphonic nature of Scottish modernism, devised from an artistic ideology with multiple echoes and related to the fragmentation of the nationalist movement, bred a new vision of Scottish identity. Marie-Odile Pittin-Hédon studies a recent development in Scottish literature and criticism, away from the critical commonplace that describes how Scottish culture has been aligned with Scottish nationalism. In her view, the "representational trope" is at last being abandoned, leading to a renewal of our critical perspective that involves looking at the various ways in which the future can be envisaged, and at the variety of responses to what Riach describes as the fundamental goal for the arts-to further our understanding of our common humanity. Mélanie Cournil's paper is about James MacQueen and the "Mary Prince controversy", which started when James MacQueen, a staunch defender 
of colonial interests, issued a scathing reply to the publication of the autobiography of a former African female slave in 1831. By focusing on James MacQueen's ideology, she underlines the problematic aspect of the production of truth in abolitionist and antiabolitionist discourses, questioning the validity and legitimacy of evidence-a necessary preamble to a more general revision of Scotland's relationship with slavery in a distant past, a revision increasingly felt to be desirable. ${ }^{1}$ Wafa El Fekih Said argues that since the 1980s, there has been debate on the future of nation-states with the rise of nationalist movements in the UK, bringing to light new forms of territorial politics. At the level of Scotland, the process of devolution has enabled political actors to develop their own responses to issues affecting Scotland. As part of the nation-building project, a consensus has been reached between political actors to reconstruct the nation. One of the tenets of this nation-building project is the creation of a "multicultural scotland" and this curious intersection between nationalism and multiculturalism raises questions about the effectiveness and sustainability of multicultural strategies within a nationalist autonomist framework.

6 The rest of the issue consists of a previously unpublished paper by Émilie Berthillot on Republicans and spies across the Irish Sea and the North Channel (1912-1923), and a review of the noteworthy book edited by Camille Manfredi and Michel Byrne, BretagneÉcosse: contacts, transferts et dissonances / Brittany-Scotland: Contacts, Transfers and Dissonances (2017).

\section{NOTES}

1. See for example <www.theguardian.com/commentisfree/2017/jan/13/slave-trade-slaveryscotland-pay-debts> (last consulted 7 March 2018).

\section{AUTEUR}

CYRIL BESSON

Université Grenoble Alpes 